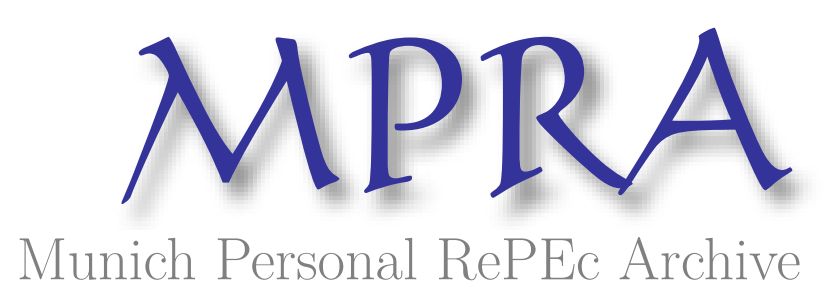

\title{
Cost Competitiveness Comparisons and Convergence in China
}

Kang, Lili and Peng, Fei

5 November 2012

Online at https://mpra.ub.uni-muenchen.de/42449/

MPRA Paper No. 42449, posted 05 Nov 2012 14:30 UTC 


\title{
Cost Competitiveness Comparisons and Convergence in
}

\section{China}

\author{
Lili Kang*, Fei Peng**
}

* Corresponding author. Institute of Economics, School of Social Sciences, Tsinghua University, Tsinghua Yuan No. 1, Ming-Zhai 220, Beijing, 100084, P.R.China.

E-mail address: lilikang@mail.tsinghua.edu.cn

**Centre of Research on the Economy and the Workplace (CREW), Business School, University of Birmingham, $U K$

\begin{abstract}
This paper examines provincial disparities and convergence of sectors in China from a labour cost perspective. We find that the provinces in the Northeast and Coastal regions have strong advantages in the manufacturing sector, while the Primary sector, Construction and Real estate sectors have better cost competitiveness in the Interior and West regions. The decrease of relative unit labour cost (RULC) is mainly due to the faster growth rates of relative labour productivity (RLP) than the growth rate of relative nominal labour costs (RNLC) in most cases. A decomposition analysis shows that there are much more cost competitiveness gains, as well as relative decrease of nominal labour costs and labour productivity improvement during the period 1978-1995 than the years afterwards. We find the fast convergence of RULC is consistent with the fast converging RLP among provinces with static wages, suggesting the importance of institutional factors such as rigid wage setting in Chinese labour markets.
\end{abstract}

Keywords: Unit Labour Cost, Regional Development Planning, China

JEL classification: J30, R58 


\section{Introduction}

Unit labour costs are widely used as a straightforward yard-stick for international competitiveness comparisons (van Ark et al., 2005). Notable studies between China and other economies include UNCTAD (2002) computing unit labour costs in manufacturing for China relative to the US, Sweden and some non-EU countries in 1998. Cox and Koo (2003) calculate labour productivity of China relative to the US and Mexico in 2001. Banister (2005) report labour costs of Chinese manufacturing in 2002, but does not include productivity or unit labour costs analysis. Szirmai et al. (2005) provide a long-run series of labour productivity relative to the US for 21 manufacturing subsectors in China from 1980 to 2002. However, concerning the enormous population and gigantic regional gaps within China, these international comparisons can only reveal a broad view of Chinese cost competitiveness.

This paper applies the unit labour cost method to analyse competitiveness across provinces and sectors within China over the period 1978-2009. Although analyses on the factors driving the disparities of unit labour costs in China have continuously induced great interest of both academy and practitioners, especially as the information is to be useful in a policy context (Peneder, 2009), the literature of internal comparison on labour costs within China is still very rare. Ceglowski and Golub (2007) analyse China's labour productivity and unit labour costs in the aggregated manufacturing over the period 1980-2002, but provide no information for the service sectors and regional disparities. Chen et al. (2009) focus on comparisons of relative levels of productivity, labour compensation, unit labour costs and convergence trends for 28 manufacturing subsectors and 30 provinces for only two years (1995 and 2004). They argue that unit labour costs decline at the aggregated level in China, because labour productivity growth is faster than the labour compensation growth. Labour-intensive industries are more likely to converge, whereas capital-skill intensive industries tended to diverge in China. However, they do not consider the fast developing service sectors in China, which is our contribution in this paper.

Therefore, we investigate the Chinese internal provincial unit labour costs and its two components, i.e. labour productivity and labour compensation across nine one-digit sectors from 1978 to 2009, to figure out regional development strategies according to their cost advantage. Sectoral competitive advantage has been shifted by the relative nominal wages and productivity growth across provinces within one country. We focus on the drivers of unit labour costs and decomposition of cost competitiveness in China. This paper is structured as follows: Section 2 introduces the measure method and discusses the construction of the dataset; Section 3 outlines findings and examines competitive differences by province and sector; Section 4 provides a decomposition of unit labour costs growth into relative changes of productivity and nominal labour costs; Section 5 shows the convergence taken place across provinces by sector. Final section concludes. 


\section{Measurement and Data}

In order to calculate unit labour costs, we need information of value added, price deflators of value added, labour compensation, numbers of staff and workers. ${ }^{1}$ For cross-provincial comparisons, the formulas for relative unit labour costs in sector $j$ and province $p$ (baseline is Chinese national level $b$ ), i.e. $R U L C_{j}{ }^{p b}$ can be calculated by:

$$
R U L C_{j}^{p b}=\frac{U L C_{j}^{p}}{U L C_{j}^{b}}=\frac{L C_{j}^{p} / Y_{j}^{p}}{L C_{j}^{b} / Y_{j}^{b}}
$$

where $L C_{j}{ }^{p}$ and $Y_{j}{ }^{p}$ are labour compensation and value added in sector $j$ and province $p$. Similarly, $L C_{j}^{b}$ and $Y_{j}^{b}$ are labour compensation and value added in sector $j$ of the average national level.

Next, relative labour productivity in sector $j$ and province $p$, i.e. $R L P_{j}^{p b}$ can be calculated by:

$$
R L P_{j}^{p b}=\frac{L P_{j}^{p}}{L P_{j}^{b}}=\frac{Y_{j}^{p} / N_{j}^{p}}{Y_{j}^{b} / N_{j}^{b}}
$$

where $N_{j}^{p}$ is the number of staff and workers in sector $j$ in province $p . N_{j}^{b}$ is the number of staff and workers in sector $j$ of the average national level.

Finally, relative nominal labour costs in sector $j$ and province $p$, i.e. $R N L C_{j}^{p b}$ can be calculated by:

$$
R N L C_{j}^{p b}=\frac{N L C_{j}^{p}}{N L C_{j}^{b}}=\frac{L C_{j}^{p} / N_{j}^{p}}{L C_{j}^{b} / N_{j}^{b}}
$$

Since unit labour costs are all relative to the China's average national level, figures greater than one indicate relative labour costs advantage for the average national level, while figures lower than one indicate relative labour costs advantage for provinces over the average national level.

\footnotetext{
${ }^{1}$ There is no detailed annual hours worked for each sector in each province, so we use the number of staff and workers instead. Staff and workers refer to persons working in, and receive payment from units of state ownership, collective ownership, joint ownership, and shareholding ownership, foreign ownership, and ownership by entrepreneurs from Hong Kong, Macao, and Taiwan, and other types of ownership and their affiliated units.
} 
Our Chinese dataset is constructed from two sources: Hsueh and Li (1999) and Chinese Statistics Yearbooks (CSYs). Hsueh and Li (1999) provide information for fourteen sectors for 1978-1995. ${ }^{2}$ And, CSYs have information for five sectors in 1996 and 1997, fifteen sectors from 1997 to 2003, and nine sectors during 2004-2009. ${ }^{3}$ There are many missing values in the consistent nine one-digit tertiary sectors after 1995 . We have to fill up these missing values using data of tertiary sector in the 1995 such as gross value added, number of staff and workers and labour compensation from Hsueh and $\mathrm{Li}$ (1999). We derive the implicit prices of gross value added from the ratios of value added at current prices and constant prices. The price deflators of gross value added for missing tertiary sectors are assumed to be the same as the respective price deflators of the total tertiary.

\section{Basic Results}

We firstly present the findings of average relative unit labour costs (RULC), and then the drivers of cost competitiveness - relative nominal labour costs (RNLC) and relative labour productivity (RLP). The year 1994 marks the spread of "market based economy" ideas in the whole country, which was started from Deng Xiaoping's "South Trip" in 1992. ${ }^{4}$ The year 1994 also relate to the decentralization of fiscal revenue to promote economic growth because local governments are better positioned than the central government to locate and monitor the fiscal expenditure more efficiently, which reinforced imposition of hard budget constraints on SOEs (Qian and Weingast, 1997; Ma and Norregaard, 1998; Oates, 1972). Thus, we follow the suggestion of Fleisher et al. (2010) to use the year 1994 as a structural break for the economic transition process in China and divide the entire time period into two parts:

\footnotetext{
${ }^{2}$ The fourteen sectors are total economy; primary sector; total manufacturing; construction; transportation, post and telecommunications; wholesale and retail trade; banking and insurance; real estate; social service; health, sports and welfare; education, culture, arts and television broadcasting; science research and general technical services; government agencies, party agencies and social organization.

${ }^{3}$ The five sectors in 1996 and 1997 are total economy; primary sector; total manufacturing; construction; transportation, post and telecommunications; wholesale and retail trade. The fifteen sectors in 1997-2003 are total economy; primary sector; total manufacturing; construction; service for farming, forestry, animal husbandry and fishery; geological prospecting and water management (conservancy); transportation, post and telecommunications; wholesale and retail trade; banking and insurance; real estate; social services; health care, sports and social welfare; education, culture and arts, radio, film and television; scientific research and polytechnic services; government agencies, party agencies, and social organization. The nine sectors in 2004-2009 are total economy; primary sector; total manufacturing; construction; transportation, post and telecommunications; wholesale and retail trade; accommodation; banking and insurance and real estate.

${ }^{4}$ In the spring of 1992, Deng Xiaoping visited the east region of China (Guangdong and Shanghai). His main idea was "To Get Rich Is Glorious".
} 
before 1995 and afterwards and also compare results for these two periods.

We investigate the extent to which competitiveness, defined by relative unit labour costs, is determined by nominal labour cost advantage or a relative productivity advantage. A relative unit labour costs lower than one with respect to the average national level indicates a relatively competitive situation for a province. It implies that its labour costs are considerably lower, or its labour productivity is considerably higher. Each of these outcomes is likely to have different policy implications and from this perspective, it is useful to have a better understanding of which component of relative unit labour costs measurement is driving the level. From the perspective of understanding the disparities, the most interesting sectors are those where there is the greatest gap between nominal labour costs and labour productivity.

Table 1 shows the average relative unit labour costs in nine one-digit sectors for the cross-provincial comparisons within China. The average RULCs decrease from 1978-1995 to 1995-2009 in most cases as we expect. The structural changes of RULCs highlight the industrialization process of each province in China. Across sectors, the highest relative unit labour costs occur in Finance $(\mathrm{J})$ for most provinces, which is consistent with the high price of physical and human capital in this sector. The RULCs are especially high in the provinces in the West region (such as Shanxi and Gansu), while the rich provinces in the Coastal region (such as Shanghai and Jiangsu) have relatively lower labour costs in Finance. It is because the Finance sector is easy to be prosperous in the Coastal region, associated with their special features in the Chinese financial history. Shanghai and Beijing are the finance centres attracting funds worldwide. In addition to huge foreign investments and advanced banking system, Zhejiang, Jiangsu and Fujian also have traditional informal finance from citizens and foreign remittances.

On the contrary, the relative unit labour costs in Education (M) and Health (N) sectors are quite high in the rich provinces in the Coastal region (such as Shanghai, Jiangsu and Guangdong), while relatively lower in the Anhui, Guangxi, Guizhou and Hunan provinces, which locate in the Interior and West regions. It suggests a labour cost advantage for these provinces in the Interior and West regions to accumulate human capital for further economic growth and catching-up with the provinces in the Coastal region. Thus, provinces should develop the specific industries according to their cost advantage (see the bold values in Table 1).

The Primary sector (AtoB), Construction (F) and Real estate (K) sectors are the most advantageous sectors for the provinces in the Interior and West regions (such as Guangxi, Guizhou, Henan and Qinghai), which is determined by their vast land and low population densities. The provinces in the Industrial Northeast and rich Coastal regions (such as Heilongjiang, Shandong and Hubei) should encourage the Manufacturing (D) sector. The Trade (G) sector has lower unit labour costs in Shanxi, Heilongjiang, Fujian and Shandong than those in other provinces. The three richest 
provinces (Beijing, Shanghai and Guangdong*) and some provinces in the Interior region (such as Shanxi, Anhui, Jiangxi and Sichuan*) have cost advantages in transportation (I) sector possibly due to rich capital endowment and geographical advantages of central location.

\section{(Table 1 around here)}

Table 2 and 3 try to dig out the drivers of cost competitiveness: the average relative labour productivity and relative nominal labour costs by province, compared with the average national level over two time periods. We find that the decrease of relative unit labour costs in Table 1 occurs mainly because the growth rate of relative labour productivity is higher than the growth rate of relative nominal labour costs.

In Table 2, the bold values show the provinces' labour productivity advantage on national levels. We can see that the relative labour productivities after 1995 are much higher than those before 1995, especially appears in the rich provinces in the Coastal region (such as Jiangsu, Zhejiang, Shandong and Guangdong*), which benefit mostly from the "market based economy" launched from 1992. The provinces in the West region (Guangxi, Guizhou and Shaanxi) only have higher relative labour productivity in the Primary sector (AtoB) than other provinces. Comparing to other sectors, most provinces has higher relative labour productivity than the average national level in the Primary sector (AtoB), such as Zhejiang, Shandong, Henan and Sichuan*. These provinces are well known as "a land flowing with fish and rice" in Chinese history.

\section{(Table 2 around here)}

Table 3 represents the relative nominal labour costs comparing to the average national level, thus the bold values suggests the provincial cost advantage. As expected, the provinces in the Northeast region (Liaoning, Jilin and Heilongjiang) and in the West region (Inner Mongolia, Guangxi, Sichuan, Guizhou, Yunnan, Shaanxi, Gansu, Qinghai, Ningxia and Xinjiang) have lower relative nominal labour costs than national level.

In the 1980s, the regional wages were similar to each other due to a rigid labour market, until Deng Xiaoping's "South Trip" in 1992 which changes the wage structure in China and has strong effect in the Coastal region. The industrial Northeast region was full of loss-incurring state owned enterprises (SOEs), and the reform of "hardening of SOEs' budget constraints" in 1994 improved the efficiency of the SOEs and promote economic growth with the expense of huge layoff (Qian and Weingast, 1997; Ma and Norregaard, 1998; Oates, 1972; Appleton et al., 2002).

(Table 3 around here) 


\section{Decompositions of relative unit labour costs}

Changes in relative unit labour costs can be decomposed into two component parts: the changes of relative nominal labour costs per hour $(r n l c)$ and relative productivity $(r l p)$ as follows:

$$
\Delta \ln (x) c=\Delta \ln k n l) c-\Delta \ln k l p
$$

where a negative change in dulc (unit labour costs) indicates gain of province competitiveness, and a negative change in dnlc (nominal labour costs) indicates a relative decrease in province nominal labour costs. A positive change in $d l p$ (labour productivity) indicates a relative improvement in province labour productivity.

Table 4 and 5 decompose the competitiveness gains or losses of the 28 provinces and the nine one digit sectors. Overall, there are much more cost competitiveness gains through decreasing relative nominal labour costs and increasing labour productivity before 1995 than afterwards. During 1978-1995, cost competitiveness gains still exist after labour productivity improvement offset increase of nominal labour costs for provinces in the Coastal region (such as Beijing, Shanghai, Jiangsu, Zhejiang and Fujian). In 1995-2009, Primary sector (AtoB), Construction (F) and Transportation (I) experience more cost competitiveness gains than other sectors. Among provinces, only one province - Guangxi in the West region appears cost competitiveness gains in all sectors due to the sharp relative decrease of nominal labour costs over the whole time period.

(Table 4 around here)

(Table 5 around here)

\section{Convergence in RULC, RLP and RNLC}

To have a better understanding of the degree of convergence that has taken place across provinces, we further look at the dispersion of the relative levels of ULC, LP and NLC. Figure 1 presents the coefficients of variations of RULC for provincial comparisons from 1978 to 2009. The Trade (G) and Real Estate (K) sectors have convergence trend over time, especially from 1978 to 1995. The Manufacturing (D), Transportation (I) and Health (N) sectors have "W" trend with sharp divergence and convergence from 1990 to 1997 . The disparity of Finance (J) sector is stable before 1998, then has sharp divergence until 2000, then convergence quickly afterwards. The disparities of Primary (AtoB), Construction (F) and Education (M) sectors are stable before 1993 but diverge afterwards.

(Figure 1 around here) 
Table 6 shows the annual growth rates of coefficients of variations of RULC, RLP and RNLC for the provincial comparisons by 9 sectors over 1978-1995 and 1995-2009. The RULC convergence appear in all sectors with the highest growth rate (-0.06) in Education (M) before 1995, but only in Finance (J) after 1995. The convergence of RLP and RULC occur in Primary (AtoB) sector, Manufacturing (D), Real estate (K), Education $(\mathrm{M})$ and Health $(\mathrm{N})$ sectors in one or both time periods. The RNLC diverges in Trade $(\mathrm{G})$ and Transportation (I) in the whole time periods.

(Table 6 around here)

\section{Conclusions}

In this paper, we examine Chinese internal provincial disparities and convergence from the labour cost perspective. Analysis on the drivers of unit labour costs and decomposition of cost competitiveness help us understand how provinces compete with each other. First, regarding to the relative unit labour costs (RULC), provinces should develop the specific industries according to their cost advantages. The provinces in the Northeast and Coastal have strong advantages in the manufacturing sector. However, gaining more cost competitiveness in the Primary sector, Construction and Real estate sectors are best strategies for the provinces in the Interior and West. Developing transportation sector is also a good direction for the provinces in the Interior possibly due to their central geographic location.

Second, the two drivers of RULC are relative nominal labour costs (RNLC) and relative labour productivity (RLP). We find that the decrease of RULC is mainly because the growth rates of RLP are higher than the growth rates of RNLC in most cases. Third, the decomposition analysis of cost competitiveness across provinces shows many interesting points. There are much more cost competitiveness gains, relative decrease of nominal labour costs and labour productivity improvement during 1978-1995 than afterwards. Finally, we find convergence of RULC is more prominent before 1995 than afterwards for provincial comparisons. The fast convergence of RULC is consistent with the fast converging RLP among provinces with static wages. It may suggest the importance of institutional factors such as rigid wage setting in Chinese labour markets. 


\section{References}

Appleton, Simon, Knight, John, Song, Lina and Xia, Qingjie 2002. Labor retrenchment in China Determinants and consequences. China Economic Review, 13, 252-275.

Banister, Judith 2005. Manufacturing earnings and compensation in China. Monthly Labor Review, Aug.

Ceglowski, Janet and Golub, Stephen 2007. Just How Low are China's Labour Costs? The World Economy, 30, 597-617.

Chen, Vivian W., Wu, Harry X. and Van Ark, Bart 2009. More Costly or More Productive? Measuring Changes in Competitiveness in Manufacturing across Regions in China. Review of Income and Wealth, 55.

Cox, W. M. and Koo, J. 2003. China: Awakening Giant. Southwest Economy, Federal Reserve Bank of Dallas, 5.

Fleisher, Li, Haizheng and Zhao, Min Qiang 2010. Human capital, economic growth, and regional inequality in China. Journal of Development Economics, 92, 215-231.

Hsueh, T. and Li, Q. 1999. China's national income, 1952-1995. Boulder: Westview Press.

Ma, J. and Norregaard, J 1998. China's Fiscal Decentralization. International Monetary Fund paper

Oates, W.E. 1972. Fiscal federalism. Harcourt Brace Jovanovich, New York.

Peneder, Michael 2009. Sectoral Growth Drivers and Competitiveness in the European Union. European Commission book.

Qian and Weingast, Barry R. 1997. Federalism as a Commitment to Perserving Market Incentives. The Journal of Economic Perspectives, 11, 83-92.

Szirmai, Adam, Ren, Ruoen and Bai, Manyin 2005. Chinese Manufacturing Performance in Comparative Perspective, 1980-2002. Working paper.

Unctad 2002. China's Accession to WTO: Managing Integration and Industrialization. Trade and Development Report, 141-174.

Van Ark, Bart, Stuivenwold, Edwin and Ypma, Gerard 2005. Unit Labour Costs, Productivity and International Competitiveness. GGDC Research Memorandum GD-80. 
Table 1 Relative Unit labour costs (1978-1995 and 1995-2009)

\begin{tabular}{|c|c|c|c|c|c|c|c|c|c|c|}
\hline Province & Period & AtoB & $\mathrm{D}$ & $\mathrm{F}$ & G & I & $\mathrm{J}$ & $\mathrm{K}$ & M & $\mathrm{N}$ \\
\hline \multirow[t]{2}{*}{ Beijing } & $78-95$ & 1.13 & 2.54 & 2.36 & 1.24 & 1.42 & 6.22 & 3.54 & 2.94 & 2.37 \\
\hline & $95-09$ & 0.97 & 1.63 & 1.89 & 1.6 & 0.87 & 0.44 & 2.04 & 1.02 & 1.52 \\
\hline \multirow[t]{2}{*}{ Tianjin } & $78-95$ & 1.35 & 2.49 & 2.96 & 1.67 & 2.01 & 13.64 & 5.43 & 3.22 & 3.09 \\
\hline & $95-09$ & 1.49 & 1.37 & 2.06 & 1.48 & 1.62 & 0.93 & 2.38 & 1.09 & 1.17 \\
\hline \multirow[t]{2}{*}{ Hebei } & $78-95$ & 1.49 & 3.5 & 2.6 & 2.1 & 2.41 & 2.64 & 5.97 & 2.95 & 3.42 \\
\hline & $95-09$ & 0.96 & 1.03 & 1.16 & 1.85 & 1.15 & 1.37 & 1.26 & 1.1 & 1.13 \\
\hline \multirow[t]{2}{*}{ Shanxi } & $78-95$ & 1.46 & 3.99 & 3.35 & 2.47 & 2.86 & 3.95 & 5.64 & 3.17 & 3.27 \\
\hline & $95-09$ & 0.87 & 1.34 & 1.37 & 0.88 & 0.98 & 1.04 & 1.44 & 0.99 & 0.82 \\
\hline \multirow[t]{2}{*}{ Inner Mongolia } & $78-95$ & 1.27 & 3.86 & 2.85 & 2.81 & 2.78 & 7.06 & 4.96 & 3.15 & 3.26 \\
\hline & $95-09$ & 1 & 1.31 & 1.57 & 1.25 & 0.93 & 3.69 & 1.51 & 1.27 & 1.1 \\
\hline \multirow[t]{2}{*}{ Liaoning } & $78-95$ & 1.53 & 2.72 & 2.8 & 1.79 & 2.22 & 2.07 & 5.68 & 2.7 & 2.58 \\
\hline & $95-09$ & 1 & 1.08 & 1.46 & 1 & 0.86 & 1.8 & 1.45 & 1.14 & 1.53 \\
\hline \multirow[t]{2}{*}{ Jilin } & $78-95$ & 1.43 & 4 & 3.37 & 5.07 & 2.98 & 9.75 & 4.27 & 2.99 & 3.1 \\
\hline & $95-09$ & 0.96 & 1.15 & 0.9 & 1.08 & 1.08 & 2.37 & 1.21 & 1.09 & 1.09 \\
\hline \multirow[t]{2}{*}{ Heilongjiang } & $78-95$ & 1.47 & 3.21 & 3.03 & 4 & 2.71 & 9.7 & 6.29 & 3.21 & 3.26 \\
\hline & $95-09$ & 1.19 & 0.85 & 1.05 & 0.98 & 1.41 & 2.66 & 1.52 & 1.01 & 1.46 \\
\hline \multirow[t]{2}{*}{ shanghai } & $78-95$ & 1.32 & 2.43 & 2.63 & 1.32 & 2.08 & 1.13 & 2.26 & 3.23 & 3.22 \\
\hline & $95-09$ & 1.3 & 1.52 & 1.85 & 1.42 & 0.86 & 0.38 & 1.8 & 1.37 & 1.44 \\
\hline \multirow[t]{2}{*}{ Jiangsu } & $78-95$ & 1.56 & 3.05 & 2.44 & 2.39 & 2.81 & 1.45 & 2.74 & 2.67 & 2.94 \\
\hline & 95-09 & 1.25 & 1.25 & 1.21 & 1.17 & 1.52 & 0.79 & 1.28 & 1.23 & 1.28 \\
\hline \multirow[t]{2}{*}{ Zhejiang } & $78-95$ & 1.4 & 3.87 & 2.97 & 1.58 & 3.52 & 2.41 & 5.54 & 3.16 & 2.68 \\
\hline & $95-09$ & 1.3 & 1.14 & 1.82 & 1.44 & 1.57 & 0.62 & 1.1 & 1.02 & 0.81 \\
\hline \multirow[t]{2}{*}{ Anhui } & $78-95$ & 1.56 & 3.62 & 3.17 & 2.5 & 2.91 & 8.08 & 2.8 & 3.5 & 3.57 \\
\hline & $95-09$ & 1.05 & 1.05 & 1.08 & 1.05 & 0.46 & 1.25 & 0.87 & 0.74 & 0.63 \\
\hline \multirow[t]{2}{*}{ Fujian } & $78-95$ & 1.61 & 4.76 & 3.08 & 3.62 & 3.19 & 3.8 & 4.89 & 2.92 & 2.89 \\
\hline & $95-09$ & 1.16 & 1.21 & 1.76 & 0.98 & 1 & 0.8 & 1.06 & 1.15 & 1.11 \\
\hline \multirow[t]{2}{*}{ Jiangxi } & $78-95$ & 1.55 & 3.8 & 3.27 & 2.84 & 3.86 & 11.72 & 3.39 & 1.83 & 1.74 \\
\hline & $95-09$ & 0.98 & 1.14 & 0.89 & 1.16 & 0.86 & 1.5 & 0.83 & 1.23 & 1.36 \\
\hline \multirow[t]{2}{*}{ Shandong } & $78-95$ & 1.45 & 3.53 & 2.53 & 2.79 & 2.11 & 3.89 & 2.33 & 2.57 & 2.37 \\
\hline & $95-09$ & 1.25 & 0.98 & 1.28 & 0.99 & 1.21 & 2.58 & 0.99 & 1.21 & 0.93 \\
\hline \multirow[t]{2}{*}{ Henan } & $78-95$ & 1.55 & 3.7 & 2.78 & 2.33 & 2.06 & 4.96 & 3.03 & 2.85 & 3.07 \\
\hline & 95-09 & 0.92 & 1.31 & 0.92 & 1.18 & 1.05 & 1.21 & 1.06 & 0.93 & 1.16 \\
\hline \multirow[t]{2}{*}{ Hubei } & $78-95$ & 1.49 & 3.32 & 2.95 & 2.6 & 3.4 & 5.59 & 4.31 & 3.26 & 3.16 \\
\hline & $95-09$ & 0.99 & 0.82 & 1.35 & 1.43 & 1.45 & 0.91 & 1.57 & 1.02 & 1.07 \\
\hline \multirow[t]{2}{*}{ Hunan } & $78-95$ & 1.67 & 3.43 & 3.44 & 2.35 & 3.09 & 6.64 & 2.82 & 3.29 & 3.25 \\
\hline & 95-09 & 0.84 & 1.22 & 1.2 & 1.14 & 1.37 & 1.25 & 0.79 & 0.81 & 0.74 \\
\hline \multirow[t]{2}{*}{ Guangdong* } & $78-95$ & 1.33 & 4.8 & 2.25 & 3.77 & 2.28 & 4.07 & 4.84 & 2.19 & 2.47 \\
\hline & $95-09$ & 1.24 & 1.17 & 2.46 & 1.08 & 0.95 & 1.34 & 1.28 & 1.71 & 1.29 \\
\hline \multirow[t]{2}{*}{ Guangxi } & $78-95$ & 1.54 & 3.17 & 3.27 & 3.11 & 2.47 & 5.59 & 4.26 & 2.68 & 2.93 \\
\hline & $95-09$ & 0.77 & 1.27 & 0.86 & 0.75 & 1.14 & 8.27 & 1.26 & 0.79 & 0.86 \\
\hline
\end{tabular}




\begin{tabular}{|l|l|l|l|l|l|l|l|l|l|l|}
\cline { 2 - 9 } Sichuan* & $78-95$ & 1.57 & 3.72 & 2.94 & 1.68 & 2.19 & 6.84 & 4.03 & 3.02 & 3.21 \\
\cline { 2 - 11 } & $95-09$ & $\mathbf{0 . 9 1}$ & 1.1 & 1.33 & $\mathbf{0 . 8}$ & $\mathbf{0 . 8}$ & 1.29 & $\mathbf{0 . 9 6}$ & $\mathbf{0 . 9 7}$ & $\mathbf{0 . 8 6}$ \\
\hline \multirow{3}{*}{ Guizhou } & $78-95$ & 1.57 & 3.82 & 2.99 & 2.4 & 2.14 & 6.47 & 6.25 & 3.65 & 3.49 \\
\cline { 2 - 11 } & $95-09$ & $\mathbf{0 . 7 9}$ & 1.07 & $\mathbf{0 . 8 8}$ & $\mathbf{0 . 8 4}$ & 1.19 & 1.3 & $\mathbf{0 . 9 4}$ & $\mathbf{0 . 8 1}$ & $\mathbf{0 . 6 7}$ \\
\hline \multirow{3}{*}{ Yunnan } & $78-95$ & 1.66 & 2.25 & 2.75 & 3.43 & 2.15 & 3.62 & 5.76 & 2.44 & 2.33 \\
\cline { 2 - 11 } & $95-09$ & 1.95 & 6.12 & 1.96 & 1.77 & 2.78 & 4.86 & 2.88 & 2.26 & 1.5 \\
\hline Shaanxi & $78-95$ & 1.56 & 4.18 & 3.14 & 2.71 & 2.53 & 19.11 & 6.29 & 3.4 & 3.6 \\
\cline { 2 - 11 } & $95-09$ & $\mathbf{0 . 9 3}$ & 1.06 & $\mathbf{0 . 7}$ & 1.46 & 1.16 & 1.78 & 2.06 & 1 & 1.23 \\
\hline \multirow{3}{*}{ Gansu } & $78-95$ & 1.5 & 4.54 & 4.07 & 1.82 & 3.53 & 10.59 & 7.69 & 3.03 & 3.56 \\
\cline { 2 - 11 } & $95-09$ & $\mathbf{0 . 8 6}$ & 1.52 & $\mathbf{0 . 9 4}$ & 1.49 & 1.24 & 1.88 & 2.34 & 1.16 & 1.56 \\
\hline \multirow{3}{*}{ Qinghai } & $78-95$ & 1.61 & 4.83 & 3.3 & 1.65 & 4.46 & 8.2 & 7.27 & 2.77 & 3.31 \\
\cline { 2 - 11 } & $95-09$ & $\mathbf{0 . 8 4}$ & 1.13 & 1.26 & $\mathbf{0 . 8 4}$ & 1.27 & 1.59 & 2.22 & 1.09 & 1.13 \\
\hline \multirow{3}{*}{ Ningxia } & $78-95$ & 1.78 & 3.77 & 3.16 & 1.74 & 2.31 & 3.58 & 4.32 & 3.02 & 2.9 \\
\cline { 2 - 10 } & $95-09$ & 1.05 & 1.12 & 1.01 & $\mathbf{0 . 8 1}$ & $\mathbf{0 . 8 6}$ & 1.41 & 1.41 & $\mathbf{0 . 8 2}$ & 0.82 \\
\hline \multirow{3}{*}{ Xinjiang } & $78-95$ & 1.58 & 3.57 & 3.09 & 1.5 & 2.67 & 6.4 & 9.62 & 3.62 & 3.74 \\
\cline { 2 - 9 } & $95-09$ & $\mathbf{0 . 8 6}$ & $\mathbf{0 . 6 6}$ & 1.34 & 1.44 & 1.93 & 2.02 & 3.61 & 1.64 & 1.84 \\
\hline
\end{tabular}

Notes: The sectors are Primary sector (AtoB), Manufacturing (D), Construction (F), Trade (G), Transportation (I), Finance (J), Real estate (K), Education $(\mathrm{M})$ and Health $(\mathrm{N})$. The bold values represent these provinces' advantage on unit labour costs relative to national level.

Table 2 Relative labour productivity (1978-1995 and 1995-2009)

\begin{tabular}{|c|c|c|c|c|c|c|c|c|c|c|}
\hline Province & Period & AtoB & $\mathrm{D}$ & $\mathrm{F}$ & $\mathrm{G}$ & I & $\mathrm{J}$ & $\mathrm{K}$ & M & $\mathrm{N}$ \\
\hline \multirow[t]{2}{*}{ Beijing } & $78-95$ & 0.7 & 0.47 & 0.33 & 0.68 & 0.66 & 1.02 & 0.29 & 0.47 & 0.82 \\
\hline & $95-09$ & 0.87 & 0.62 & 0.49 & 0.55 & 0.63 & 2.35 & 0.38 & 1.91 & 1.1 \\
\hline \multirow[t]{2}{*}{ Tianjin } & $78-95$ & 1.16 & 0.38 & 0.42 & 0.52 & 0.58 & 0.83 & 0.26 & 0.51 & 0.38 \\
\hline & $95-09$ & 1.95 & 0.72 & 0.79 & 0.91 & 1.04 & 1.52 & 0.76 & 1.42 & 1.05 \\
\hline \multirow[t]{2}{*}{ Hebei } & $78-95$ & 1.66 & 0.43 & 0.4 & 0.56 & 0.61 & 0.42 & 0.51 & 0.42 & 0.45 \\
\hline & $95-09$ & 2.57 & 1.13 & 0.88 & 0.78 & 1.3 & 0.64 & 0.84 & 0.75 & 0.8 \\
\hline \multirow[t]{2}{*}{ Shanxi } & $78-95$ & 1.52 & 0.37 & 0.39 & 0.37 & 0.44 & 0.41 & 0.28 & 0.45 & 0.46 \\
\hline & $95-09$ & 1.58 & 0.77 & 0.58 & 0.44 & 0.76 & 0.62 & 0.53 & 0.84 & 0.73 \\
\hline \multirow[t]{2}{*}{ Inner Mongolia } & $78-95$ & 0.28 & 0.25 & 0.33 & 0.42 & 0.36 & 0.25 & 0.27 & 0.43 & 0.38 \\
\hline & $95-09$ & 0.34 & 0.68 & 0.73 & 0.88 & 0.79 & 0.27 & 0.52 & 0.8 & 0.87 \\
\hline \multirow[t]{2}{*}{ Liaoning } & $78-95$ & 0.37 & 0.33 & 0.27 & 0.54 & 0.62 & 0.44 & 0.22 & 0.51 & 0.55 \\
\hline & $95-09$ & 0.48 & 0.83 & 0.77 & 1.51 & 0.83 & 0.59 & 0.83 & 1.09 & 1.15 \\
\hline \multirow[t]{2}{*}{ Jilin } & 78-95 & 0.51 & 0.25 & 0.29 & 0.27 & 0.3 & 0.26 & 0.23 & 0.44 & 0.37 \\
\hline & 95-09 & 0.61 & 0.64 & 0.8 & 0.76 & 0.47 & 0.29 & 0.47 & 0.75 & 0.67 \\
\hline \multirow[t]{2}{*}{ Heilongjiang } & $78-95$ & 0.16 & 0.4 & 0.33 & 0.3 & 0.36 & 0.41 & 0.24 & 0.49 & 0.51 \\
\hline & 95-09 & 0.22 & 1 & 0.52 & 0.61 & 0.49 & 0.37 & 0.47 & 0.83 & 0.85 \\
\hline \multirow[t]{2}{*}{ shanghai } & 78-95 & 0.57 & 0.77 & 0.78 & 0.89 & 0.68 & 1.12 & 0.55 & 0.55 & 0.42 \\
\hline & 95-09 & 1.72 & 1.38 & 1.69 & 1.33 & 0.92 & 2.46 & 1.03 & 2.17 & 1.42 \\
\hline Jiangsu & $78-95$ & 1.22 & 0.47 & 0.85 & 0.56 & 0.47 & 0.62 & 0.59 & 0.5 & 0.46 \\
\hline
\end{tabular}




\begin{tabular}{|c|c|c|c|c|c|c|c|c|c|c|}
\hline & $95-09$ & 1.58 & 1.12 & 1.77 & 1.26 & 1.04 & 1.29 & 1.37 & 1.13 & 1.02 \\
\hline \multirow[t]{2}{*}{ Zhejiang } & $78-95$ & 3.05 & 0.56 & 0.54 & 1.12 & 0.72 & 0.42 & 0.65 & 0.49 & 0.51 \\
\hline & $95-09$ & 5.54 & 1.44 & 0.71 & 1.96 & 1.53 & 0.96 & 1.18 & 1.3 & 1.23 \\
\hline \multirow[t]{2}{*}{ Anhui } & $78-95$ & 1.6 & 0.35 & 0.45 & 0.53 & 0.44 & 0.38 & 0.4 & 0.39 & 0.37 \\
\hline & $95-09$ & 1.82 & 0.92 & 0.8 & 0.67 & 0.81 & 0.54 & 0.89 & 0.75 & 0.88 \\
\hline \multirow[t]{2}{*}{ Fujian } & $78-95$ & 1.12 & 0.36 & 0.65 & 0.95 & 0.94 & 0.52 & 0.55 & 0.53 & 0.47 \\
\hline & $95-09$ & 2.04 & 0.7 & 0.93 & 1.6 & 2.07 & 1.06 & 1.33 & 1.02 & 1.11 \\
\hline \multirow[t]{2}{*}{ Jiangxi } & $78-95$ & 0.57 & 0.25 & 0.57 & 0.33 & 0.39 & 0.32 & 0.61 & 0.51 & 0.48 \\
\hline & $95-09$ & 0.77 & 0.59 & 1.02 & 0.69 & 0.87 & 0.54 & 0.85 & 0.68 & 0.55 \\
\hline \multirow[t]{2}{*}{ Shandong } & $78-95$ & 3.68 & 0.5 & 1.06 & 0.76 & 0.88 & 0.57 & 0.69 & 0.56 & 0.63 \\
\hline & $95-09$ & 4.65 & 0.93 & 1.22 & 1.04 & 1.48 & 1.08 & 1.37 & 1.15 & 1.2 \\
\hline \multirow[t]{2}{*}{ Henan } & $78-95$ & 3.15 & 0.38 & 0.45 & 0.39 & 0.6 & 0.32 & 0.55 & 0.49 & 0.48 \\
\hline & $95-09$ & 3.11 & 0.93 & 0.56 & 0.41 & 0.93 & 0.4 & 0.74 & 0.62 & 0.79 \\
\hline \multirow[t]{2}{*}{ Hubei } & $78-95$ & 0.51 & 0.32 & 0.45 & 0.45 & 0.32 & 0.31 & 0.34 & 0.36 & 0.37 \\
\hline & 95-09 & 0.66 & 0.71 & 0.64 & 0.71 & 0.6 & 0.72 & 0.72 & 0.83 & 0.86 \\
\hline \multirow[t]{2}{*}{ Hunan } & $78-95$ & 0.7 & 0.33 & 0.55 & 0.54 & 0.43 & 0.37 & 0.46 & 0.5 & 0.44 \\
\hline & $95-09$ & 1.68 & 0.85 & 0.73 & 0.93 & 0.83 & 0.55 & 0.78 & 1.03 & 1.06 \\
\hline \multirow[t]{2}{*}{ Guangdong* } & $78-95$ & 0.59 & 0.52 & 0.61 & 0.72 & 0.68 & 0.39 & 0.61 & 0.59 & 0.66 \\
\hline & $95-09$ & 0.96 & 1.11 & 1 & 1.37 & 1.46 & 0.89 & 1.38 & 0.98 & 0.96 \\
\hline \multirow[t]{2}{*}{ Guangxi } & $78-95$ & 0.86 & 0.37 & 0.35 & 0.82 & 0.48 & 0.3 & 0.41 & 0.4 & 0.42 \\
\hline & 95-09 & 1.11 & 0.88 & 0.87 & 1.09 & 0.86 & 0.41 & 0.69 & 0.71 & 0.84 \\
\hline \multirow[t]{2}{*}{ Sichuan* } & $78-95$ & 3.5 & 0.43 & 0.56 & 0.77 & 0.47 & 0.45 & 0.61 & 0.58 & 0.57 \\
\hline & 95-09 & 2.93 & 0.7 & 0.52 & 0.9 & 0.79 & 0.8 & 0.82 & 0.86 & 0.87 \\
\hline \multirow[t]{2}{*}{ Guizhou } & $78-95$ & 1.65 & 0.29 & 0.37 & 0.42 & 0.36 & 0.25 & 0.31 & 0.33 & 0.38 \\
\hline & $95-09$ & 2.26 & 0.61 & 0.37 & 0.5 & 0.63 & 0.59 & 0.6 & 0.74 & 0.98 \\
\hline \multirow[t]{2}{*}{ Yunnan } & $78-95$ & 0.54 & 0.48 & 0.4 & 0.69 & 0.37 & 0.35 & 0.29 & 0.51 & 0.66 \\
\hline & 95-09 & 0.65 & 1.01 & 0.83 & 0.71 & 0.56 & 0.58 & 0.6 & 0.61 & 0.88 \\
\hline \multirow[t]{2}{*}{ Shaanxi } & $78-95$ & 1.43 & 0.26 & 0.38 & 0.34 & 0.44 & 0.35 & 0.28 & 0.45 & 0.45 \\
\hline & 95-09 & 1.32 & 0.51 & 0.82 & 0.46 & 0.67 & 0.41 & 0.4 & 0.87 & 0.77 \\
\hline \multirow[t]{2}{*}{ Gansu } & $78-95$ & 0.61 & 0.31 & 0.38 & 0.69 & 0.36 & 0.29 & 0.28 & 0.42 & 0.34 \\
\hline & $95-09$ & 0.69 & 0.52 & 0.7 & 0.56 & 0.4 & 0.4 & 0.4 & 0.48 & 0.64 \\
\hline \multirow[t]{2}{*}{ Qinghai } & $78-95$ & 0.4 & 0.27 & 0.44 & 0.65 & 0.27 & 0.32 & 0.43 & 0.64 & 0.53 \\
\hline & $95-09$ & 0.58 & 0.77 & 0.87 & 0.71 & 0.49 & 0.65 & 0.36 & 0.97 & 0.66 \\
\hline \multirow[t]{2}{*}{ Ningxia } & $78-95$ & 0.26 & 0.3 & 0.63 & 0.5 & 0.41 & 0.4 & 0.31 & 0.45 & 0.38 \\
\hline & $95-09$ & 0.4 & 0.73 & 1.06 & 0.78 & 0.84 & 0.81 & 0.57 & 1.14 & 0.97 \\
\hline \multirow[t]{2}{*}{ Xinjiang } & $78-95$ & 0.08 & 0.35 & 0.42 & 0.61 & 0.39 & 0.35 & 0.3 & 0.43 & 0.36 \\
\hline & $95-09$ & 0.12 & 1.2 & 0.93 & 0.73 & 0.72 & 0.61 & 0.47 & 0.82 & 0.62 \\
\hline
\end{tabular}

Notes: The bold values represent these provinces' advantage on labour productivity relative to national level. 
Table 3 Relative Nominal Labour costs (1978 - 1995 and 1995 - 2009)

\begin{tabular}{|c|c|c|c|c|c|c|c|c|c|c|}
\hline Province & Period & AtoB & $\mathrm{D}$ & $\mathrm{F}$ & G & I & $\mathrm{J}$ & $\mathrm{K}$ & M & $\mathrm{N}$ \\
\hline \multirow[t]{2}{*}{ Beijing } & $78-95$ & 0.64 & 1.01 & 0.63 & 0.72 & 0.86 & 2.31 & 0.66 & 0.84 & 1.59 \\
\hline & $95-09$ & 0.80 & 0.98 & 0.92 & 0.78 & 0.52 & 1.03 & 0.76 & 1.94 & 1.65 \\
\hline \multirow[t]{2}{*}{ Tianjin } & $78-95$ & 1.42 & 0.76 & 0.88 & 0.75 & 0.94 & 0.66 & 0.95 & 1.41 & 0.85 \\
\hline & $95-09$ & 2.89 & 0.97 & 1.62 & 1.32 & 1.64 & 1.25 & 1.77 & 1.52 & 1.20 \\
\hline \multirow[t]{2}{*}{ Hebei } & $78-95$ & 2.30 & 1.07 & 0.81 & 0.95 & 1.21 & 0.55 & 2.07 & 0.90 & 1.12 \\
\hline & $95-09$ & 2.47 & 1.17 & 1.01 & 1.40 & 1.49 & 0.83 & 1.04 & 0.82 & 0.89 \\
\hline \multirow[t]{2}{*}{ Shanxi } & $78-95$ & 2.14 & 1.17 & 0.94 & 0.70 & 0.92 & 0.62 & 1.06 & 1.17 & 1.32 \\
\hline & $95-09$ & 1.36 & 1.03 & 0.79 & 0.38 & 0.73 & 0.59 & 0.73 & 0.79 & 0.56 \\
\hline \multirow[t]{2}{*}{ Inner Mongolia } & $78-95$ & 0.33 & 0.70 & 0.76 & 0.89 & 0.77 & 0.90 & 0.82 & 1.02 & 0.85 \\
\hline & $95-09$ & 0.33 & 0.90 & 1.13 & 1.09 & 0.74 & 0.91 & 0.78 & 1.01 & 0.93 \\
\hline \multirow[t]{2}{*}{ Liaoning } & $78-95$ & 0.51 & 0.72 & 0.57 & 0.70 & 0.85 & 0.51 & 0.56 & 0.96 & 1.06 \\
\hline & $95-09$ & 0.48 & 0.89 & 1.12 & 1.50 & 0.72 & 0.99 & 1.20 & 1.24 & 1.75 \\
\hline \multirow[t]{2}{*}{ Jilin } & $78-95$ & 0.69 & 0.74 & 0.64 & 0.76 & 0.77 & 1.04 & 0.64 & 1.03 & 0.87 \\
\hline & $95-09$ & 0.58 & 0.74 & 0.73 & 0.80 & 0.50 & 0.51 & 0.57 & 0.81 & 0.73 \\
\hline \multirow[t]{2}{*}{ Heilongjiang } & $78-95$ & 0.22 & 0.97 & 0.72 & 0.72 & 0.86 & 1.76 & 0.88 & 1.22 & 1.17 \\
\hline & $95-09$ & 0.26 & 0.84 & 0.55 & 0.60 & 0.68 & 0.64 & 0.70 & $\mathbf{0 . 8 3}$ & 1.23 \\
\hline \multirow[t]{2}{*}{ shanghai } & $78-95$ & 0.69 & 1.53 & 1.35 & 1.04 & 1.06 & 0.65 & 0.70 & 1.11 & 0.84 \\
\hline & $95-09$ & 2.28 & 2.07 & 3.09 & 1.84 & 0.75 & 0.88 & 1.82 & 2.95 & 2.02 \\
\hline \multirow[t]{2}{*}{ Jiangsu } & $78-95$ & 1.76 & 0.99 & 1.59 & 0.88 & 0.98 & 0.63 & 1.00 & 0.99 & 0.91 \\
\hline & $95-09$ & 1.97 & 1.37 & 2.14 & 1.46 & 1.55 & 1.00 & 1.74 & 1.38 & 1.29 \\
\hline \multirow[t]{2}{*}{ Zhejiang } & $78-95$ & 3.92 & 1.34 & 1.12 & 1.31 & 1.63 & 0.48 & 1.71 & 1.08 & 0.95 \\
\hline & $95-09$ & 7.44 & 1.58 & 1.23 & 2.73 & 2.24 & 0.57 & 1.30 & 1.28 & 0.96 \\
\hline \multirow[t]{2}{*}{ Anhui } & $78-95$ & 2.39 & 0.88 & 1.11 & 1.04 & 0.89 & 1.51 & 0.73 & 0.94 & 0.94 \\
\hline & $95-09$ & 1.91 & 0.96 & 0.86 & 0.70 & 0.36 & 0.64 & 0.77 & 0.54 & 0.52 \\
\hline \multirow[t]{2}{*}{ Fujian } & $78-95$ & 1.60 & 1.02 & 1.25 & 2.10 & 1.84 & 0.99 & 1.23 & 1.03 & 0.86 \\
\hline & $95-09$ & 2.37 & 0.81 & 1.51 & 1.56 & 1.99 & 0.83 & 1.36 & 1.14 & 1.21 \\
\hline \multirow[t]{2}{*}{ Jiangxi } & $78-95$ & 0.83 & 0.69 & 1.66 & 0.86 & 1.14 & 0.91 & 1.38 & 0.74 & 0.66 \\
\hline & $95-09$ & 0.75 & 0.67 & 0.91 & 0.79 & 0.75 & 0.70 & 0.69 & 0.81 & 0.74 \\
\hline \multirow[t]{2}{*}{ Shandong } & $78-95$ & 4.96 & 1.28 & 2.04 & 0.93 & 1.41 & 1.12 & 1.07 & 1.02 & 1.08 \\
\hline & $95-09$ & 5.85 & 0.89 & 1.46 & 1.02 & 1.77 & 2.64 & 1.34 & 1.37 & 1.11 \\
\hline \multirow[t]{2}{*}{ Henan } & $78-95$ & 4.65 & 1.03 & 1.06 & 0.77 & 1.07 & 0.75 & 1.03 & 1.13 & 1.09 \\
\hline & $95-09$ & 2.87 & 1.23 & 0.51 & 0.49 & 0.96 & 0.46 & 0.76 & 0.57 & 0.91 \\
\hline \multirow[t]{2}{*}{ Hubei } & $78-95$ & 0.71 & 0.72 & 1.09 & 0.94 & 0.77 & 1.19 & 0.84 & 0.8 & 0.74 \\
\hline & $95-09$ & 0.65 & 0.58 & 0.87 & 1.01 & 0.86 & 0.62 & 1.12 & 0.85 & 0.91 \\
\hline \multirow[t]{2}{*}{ Hunan } & $78-95$ & 1.09 & 0.87 & 1.44 & 0.92 & 1.04 & 1.16 & 0.83 & 1.27 & 1.07 \\
\hline & $95-09$ & 1.36 & 1.03 & 0.87 & 1.06 & 1.14 & 0.66 & 0.61 & 0.83 & 0.78 \\
\hline \multirow[t]{2}{*}{ Guangdong* } & $78-95$ & 0.72 & 1.49 & 0.98 & 2.01 & 1.08 & 0.69 & 1.19 & 0.9 & 1.07 \\
\hline & $95-09$ & 1.19 & 1.26 & 2.04 & 1.46 & 1.28 & 1.11 & 1.71 & 1.52 & 1.18 \\
\hline \multirow[t]{2}{*}{ Guangxi } & $78-95$ & 1.24 & 0.84 & 0.83 & 1.42 & 0.88 & 1.77 & 1.12 & 0.82 & 0.89 \\
\hline & $95-09$ & 0.86 & 1.11 & 0.75 & 0.81 & 0.98 & 2.7 & 0.87 & 0.55 & 0.71 \\
\hline
\end{tabular}




\begin{tabular}{|l|l|l|l|l|l|l|l|l|l|l|} 
Sichuan* & $78-95$ & 5.17 & 1.15 & 1.25 & 1.07 & $\mathbf{0 . 8 4}$ & 1.32 & 1.55 & 1.22 & 1.25 \\
\cline { 2 - 11 } & $95-09$ & 2.66 & $\mathbf{0 . 7 5}$ & $\mathbf{0 . 6 5}$ & $\mathbf{0 . 7 2}$ & $\mathbf{0 . 6 2}$ & 1.01 & $\mathbf{0 . 7 8}$ & $\mathbf{0 . 8 3}$ & $\mathbf{0 . 7 5}$ \\
\hline \multirow{3}{*}{ Guizhou } & $78-95$ & 2.36 & $\mathbf{0 . 7 2}$ & $\mathbf{0 . 6 8}$ & $\mathbf{0 . 8 4}$ & $\mathbf{0 . 7 2}$ & $\mathbf{0 . 7 7}$ & $\mathbf{0 . 9 3}$ & $\mathbf{0 . 7 9}$ & $\mathbf{0 . 8 6}$ \\
\cline { 2 - 10 } & $95-09$ & 1.78 & $\mathbf{0 . 6 1}$ & $\mathbf{0 . 3 1}$ & $\mathbf{0 . 3 7}$ & $\mathbf{0 . 6 5}$ & $\mathbf{0 . 6 3}$ & $\mathbf{0 . 4 6}$ & $\mathbf{0 . 5 1}$ & $\mathbf{0 . 5 6}$ \\
\hline \multirow{3}{*}{ Yunnan } & $78-95$ & $\mathbf{0 . 8 2}$ & $\mathbf{0 . 6 5}$ & $\mathbf{0 . 9 2}$ & 1.31 & $\mathbf{0 . 6 3}$ & $\mathbf{0 . 9 9}$ & $\mathbf{0 . 9}$ & $\mathbf{0 . 8 3}$ & $\mathbf{0 . 7 1}$ \\
\cline { 2 - 11 } & $95-09$ & $\mathbf{0 . 6 9}$ & $\mathbf{0 . 7}$ & $\mathbf{0 . 9 6}$ & $\mathbf{0 . 6 5}$ & $\mathbf{0 . 7 1}$ & 1.51 & 0.79 & $\mathbf{0 . 7 2}$ & $\mathbf{0 . 6 3}$ \\
\hline \multirow{3}{*}{ Shaanxi } & $78-95$ & 2.1 & $\mathbf{0 . 8 1}$ & $\mathbf{0 . 9 2}$ & $\mathbf{0 . 7 8}$ & $\mathbf{0 . 8 8}$ & 2.31 & 1.02 & 1.06 & 1.15 \\
\cline { 2 - 11 } & $95-09$ & 1.23 & $\mathbf{0 . 5 4}$ & $\mathbf{0 . 5 6}$ & $\mathbf{0 . 6 5}$ & $\mathbf{0 . 7 2}$ & $\mathbf{0 . 5 8}$ & $\mathbf{0 . 7 4}$ & $\mathbf{0 . 8 1}$ & $\mathbf{0 . 8 8}$ \\
\hline \multirow{3}{*}{ Gansu } & $78-95$ & $\mathbf{0 . 8 5}$ & 1.15 & $\mathbf{0 . 8 9}$ & 1.03 & 1.16 & 1.36 & 1.23 & $\mathbf{0 . 9 9}$ & $\mathbf{0 . 8}$ \\
\cline { 2 - 10 } & $95-09$ & $\mathbf{0 . 5}$ & $\mathbf{0 . 6 7}$ & $\mathbf{0 . 6}$ & $\mathbf{0 . 7}$ & $\mathbf{0 . 4 2}$ & $\mathbf{0 . 6 6}$ & $\mathbf{0 . 8 5}$ & $\mathbf{0 . 4 8}$ & $\mathbf{0 . 8 4}$ \\
\hline \multirow{3}{*}{ Qinghai } & $78-95$ & $\mathbf{0 . 5 9}$ & $\mathbf{0 . 8 8}$ & 1.11 & $\mathbf{0 . 8 8}$ & $\mathbf{0 . 8 4}$ & 1.44 & 2.39 & 1.41 & 1.61 \\
\cline { 2 - 10 } & $95-09$ & $\mathbf{0 . 4 9}$ & $\mathbf{0 . 8 8}$ & 1.09 & $\mathbf{0 . 5 9}$ & $\mathbf{0 . 6 1}$ & $\mathbf{0 . 9 7}$ & $\mathbf{0 . 7 6}$ & 1.03 & $\mathbf{0 . 7 4}$ \\
\hline \multirow{3}{*}{ Ningxia } & $78-95$ & $\mathbf{0 . 4 2}$ & $\mathbf{0 . 8 2}$ & 1.53 & 0.72 & $\mathbf{0 . 8 1}$ & $\mathbf{0 . 7 3}$ & $\mathbf{0 . 9 3}$ & $\mathbf{0 . 9 8}$ & $\mathbf{0 . 8 6}$ \\
\cline { 2 - 10 } & $95-09$ & $\mathbf{0 . 3 2}$ & $\mathbf{0 . 7 4}$ & $\mathbf{0 . 8}$ & $\mathbf{0 . 4 9}$ & $\mathbf{0 . 5 7}$ & $\mathbf{0 . 8 3}$ & $\mathbf{0 . 6 3}$ & $\mathbf{0 . 7 5}$ & $\mathbf{0 . 6 3}$ \\
\hline \multirow{3}{*}{ Xinjiang } & $78-95$ & $\mathbf{0 . 1 2}$ & $\mathbf{0 . 8 6}$ & $\mathbf{0 . 9 5}$ & $\mathbf{0 . 6 9}$ & $\mathbf{0 . 7 2}$ & 1.1 & 1.35 & 1.03 & $\mathbf{0 . 9}$ \\
\cline { 2 - 9 } & $95-09$ & $\mathbf{0 . 1 1}$ & $\mathbf{0 . 7 7}$ & 1.23 & $\mathbf{0 . 7 3}$ & $\mathbf{0 . 9 3}$ & $\mathbf{0 . 8}$ & 1.07 & $\mathbf{0 . 9 1}$ & $\mathbf{0 . 7 1}$ \\
\hline
\end{tabular}

Notes: The bold numbers presents these provinces' advantage on nominal labour costs relative to national level.

Table 4 Decomposition of relative unit labour costs, 1978-1995 (Values have been timed 100)

\begin{tabular}{|c|c|c|c|c|c|c|c|c|c|c|}
\hline Province & $78-95$ & AtoB & D & $\mathrm{F}$ & G & I & $\mathrm{J}$ & $\mathrm{K}$ & M & $\mathrm{N}$ \\
\hline \multirow[t]{3}{*}{ Beijing } & RULC & -8 & -9 & -8 & -6 & -5 & -21 & -9 & -10 & -9 \\
\hline & NLC & -1 & -2 & 1 & 2 & -1 & -3 & 0 & 4 & -3 \\
\hline & RLP & 6 & 7 & 9 & 8 & 4 & 18 & 9 & 15 & 7 \\
\hline \multirow[t]{3}{*}{ Tianjin } & RULC & -5 & -10 & -14 & -4 & -9 & -31 & -13 & -12 & -11 \\
\hline & NLC & 2 & -1 & -1 & 1 & 2 & -1 & -5 & -5 & 1 \\
\hline & RLP & 7 & 10 & 13 & 5 & 10 & 30 & 9 & 7 & 12 \\
\hline \multirow[t]{3}{*}{ Hebei } & RULC & -4 & -12 & -11 & -7 & -8 & -12 & -15 & -10 & -10 \\
\hline & NLC & 1 & 0 & 0 & 4 & -1 & 3 & -7 & 1 & 0 \\
\hline & RLP & 5 & 12 & 10 & 10 & 7 & 15 & 9 & 11 & 10 \\
\hline \multirow[t]{3}{*}{ Shanxi } & RULC & -6 & -12 & -12 & -11 & -10 & -12 & -13 & -12 & -13 \\
\hline & NLC & -3 & -3 & -1 & -4 & 2 & 1 & -4 & -5 & -8 \\
\hline & RLP & 3 & 9 & 11 & 7 & 12 & 14 & 9 & 7 & 4 \\
\hline \multirow[t]{3}{*}{ Inner Mongolia } & RULC & -5 & -13 & -9 & -8 & -10 & -14 & -12 & -10 & -11 \\
\hline & NLC & 0 & -3 & -2 & -1 & -1 & -2 & -1 & -2 & 1 \\
\hline & RLP & 5 & 10 & 7 & 7 & 9 & 12 & 12 & 8 & 11 \\
\hline \multirow[t]{3}{*}{ Liaoning } & RULC & -6 & -10 & -9 & -8 & -9 & -11 & -14 & -9 & -8 \\
\hline & NLC & -1 & -2 & 2 & 0 & -3 & 5 & 7 & 4 & 4 \\
\hline & RLP & 6 & 8 & 11 & 8 & 6 & 16 & 21 & 13 & 12 \\
\hline
\end{tabular}




\begin{tabular}{|c|c|c|c|c|c|c|c|c|c|c|}
\hline \multirow[t]{3}{*}{ Jilin } & RULC & -4 & -12 & -15 & -15 & -9 & -17 & -12 & -10 & -11 \\
\hline & NLC & 1 & -3 & -2 & -3 & -2 & -4 & -3 & -3 & -2 \\
\hline & RLP & 5 & 9 & 13 & 12 & 7 & 13 & 9 & 8 & 8 \\
\hline \multirow[t]{3}{*}{ Heilongjiang } & RULC & -6 & -13 & -11 & -14 & -9 & -18 & -14 & -11 & -11 \\
\hline & NLC & -1 & -3 & -1 & -3 & -4 & -6 & -1 & -4 & $\mathbf{0}$ \\
\hline & RLP & 5 & 10 & 10 & 11 & 5 & 12 & 13 & 8 & 11 \\
\hline \multirow[t]{3}{*}{ shanghai } & RULC & -6 & -10 & -13 & -6 & -14 & -13 & -10 & -12 & -11 \\
\hline & NLC & -2 & -1 & 5 & 1 & -5 & 2 & 2 & 2 & 2 \\
\hline & RLP & 4 & 9 & 18 & 7 & 9 & 15 & 12 & 13 & 14 \\
\hline \multirow[t]{3}{*}{ Jiangsu } & RULC & -6 & -11 & -11 & -7 & -8 & -11 & -12 & -10 & -11 \\
\hline & NLC & 0 & 3 & 0 & 3 & 3 & 0 & 0 & -1 & 0 \\
\hline & RLP & 6 & 14 & 11 & 10 & 11 & 11 & 12 & 10 & 11 \\
\hline \multirow[t]{3}{*}{ Zhejiang } & RULC & -4 & -13 & -11 & -7 & -12 & -13 & -7 & -10 & -11 \\
\hline & NLC & 0 & 4 & 3 & 7 & 4 & 3 & 3 & 1 & 0 \\
\hline & RLP & 4 & 17 & 14 & 14 & 16 & 15 & 11 & 12 & 11 \\
\hline \multirow[t]{3}{*}{ Anhui } & RULC & -5 & -12 & -10 & -9 & -15 & -17 & -10 & -13 & -13 \\
\hline & NLC & -1 & 2 & 1 & -4 & -7 & -2 & 3 & -3 & -4 \\
\hline & RLP & 4 & 14 & 11 & 5 & 8 & 15 & 13 & 10 & 9 \\
\hline \multirow[t]{3}{*}{ Fujian } & RULC & -5 & -15 & -9 & -15 & -14 & -17 & -16 & -12 & -11 \\
\hline & NLC & 3 & 3 & 3 & 1 & 3 & -3 & 3 & 2 & 4 \\
\hline & RLP & 8 & 17 & 12 & 16 & 16 & 14 & 20 & 14 & 15 \\
\hline \multirow[t]{3}{*}{ Jiangxi } & RULC & -4 & -11 & -12 & -6 & -11 & -21 & -13 & -8 & -6 \\
\hline & NLC & -1 & 0 & -7 & 0 & -1 & -6 & -7 & 1 & 1 \\
\hline & RLP & 4 & 11 & 5 & 6 & 10 & 16 & 7 & 8 & 7 \\
\hline \multirow[t]{3}{*}{ Shandong } & RULC & -5 & -12 & -11 & -14 & -9 & -10 & -10 & -10 & -11 \\
\hline & NLC & 0 & -1 & 0 & 4 & 1 & 5 & 4 & 2 & 0 \\
\hline & RLP & 5 & 12 & 11 & 18 & 10 & 15 & 13 & 12 & 11 \\
\hline \multirow[t]{3}{*}{ Henan } & RULC & -4 & -10 & -9 & -8 & -6 & -17 & -10 & -10 & -10 \\
\hline & NLC & -1 & 3 & -2 & 0 & 3 & -5 & 1 & -1 & 0 \\
\hline & RLP & 3 & 12 & 7 & 8 & 8 & 12 & 12 & 8 & 10 \\
\hline \multirow[t]{3}{*}{ Hubei } & RULC & -5 & -14 & -10 & -8 & -9 & -17 & -12 & -12 & -8 \\
\hline & NLC & -1 & -1 & -4 & 0 & 0 & -6 & 1 & -1 & 6 \\
\hline & RLP & 4 & 13 & 7 & 9 & 10 & 10 & 13 & 11 & 14 \\
\hline \multirow[t]{3}{*}{ Hunan } & RULC & -5 & -10 & -11 & -9 & -8 & -12 & -11 & -12 & -11 \\
\hline & NLC & -1 & 1 & -2 & -1 & 1 & 1 & 1 & -2 & -1 \\
\hline & RLP & 5 & 11 & 9 & 9 & 9 & 13 & 12 & 10 & 10 \\
\hline \multirow[t]{3}{*}{ Guangdong* } & RULC & -4 & -14 & -5 & -13 & -12 & -16 & -16 & -9 & -12 \\
\hline & NLC & 3 & 2 & 7 & -3 & 2 & 3 & 7 & 9 & 3 \\
\hline & RLP & 7 & 16 & 12 & 10 & 14 & 19 & 22 & 18 & 15 \\
\hline \multirow[t]{3}{*}{ Guangxi } & RULC & -4 & -8 & -10 & -9 & -6 & 1 & -11 & -10 & -9 \\
\hline & NLC & 3 & 5 & 4 & 3 & 4 & 14 & 2 & -2 & 2 \\
\hline & RLP & 7 & 14 & 13 & 13 & 11 & 13 & 12 & 8 & 11 \\
\hline Sichuan* & RULC & -5 & -13 & -11 & -9 & -9 & -20 & -15 & -13 & -15 \\
\hline
\end{tabular}




\begin{tabular}{|c|c|c|c|c|c|c|c|c|c|c|}
\hline & NLC & -3 & -2 & -1 & -3 & -3 & -1 & 0 & -2 & -3 \\
\hline & RLP & 2 & 11 & 10 & 6 & 5 & 19 & 15 & 12 & 12 \\
\hline \multirow[t]{3}{*}{ Guizhou } & RULC & -5 & -13 & -10 & -10 & -3 & -14 & -14 & -11 & -11 \\
\hline & NLC & 1 & 1 & -3 & -1 & 5 & 0 & -1 & 2 & 2 \\
\hline & RLP & 6 & 13 & 7 & 9 & 8 & 14 & 14 & 14 & 13 \\
\hline \multirow[t]{3}{*}{ Yunnan } & RULC & -6 & -14 & -10 & -17 & -7 & -10 & -15 & -11 & -12 \\
\hline & NLC & -1 & 1 & -3 & -5 & 1 & 5 & -1 & 0 & 0 \\
\hline & RLP & 5 & 15 & 8 & 12 & 8 & 15 & 14 & 11 & 12 \\
\hline \multirow[t]{3}{*}{ Shaanxi } & RULC & -5 & -12 & -13 & -6 & -9 & -25 & -12 & -12 & -11 \\
\hline & NLC & -2 & -4 & -5 & 0 & 2 & -7 & 0 & -1 & 0 \\
\hline & RLP & 3 & 9 & 8 & 7 & 10 & 17 & 13 & 11 & 11 \\
\hline \multirow[t]{3}{*}{ Gansu } & RULC & -6 & -14 & -11 & -10 & -11 & -21 & -17 & -12 & -10 \\
\hline & NLC & -3 & -7 & -5 & -3 & -8 & -9 & -6 & -4 & -4 \\
\hline & RLP & 3 & 7 & 6 & 7 & 3 & 12 & 11 & 8 & 7 \\
\hline \multirow[t]{3}{*}{ Qinghai } & RULC & -6 & -13 & -14 & -8 & -14 & -12 & -13 & -12 & -11 \\
\hline & NLC & -1 & -3 & -6 & -3 & -5 & 2 & -8 & -6 & -12 \\
\hline & RLP & 5 & 10 & 8 & 5 & 10 & 14 & 6 & 5 & -1 \\
\hline \multirow[t]{3}{*}{ Ningxia } & RULC & -8 & -11 & -11 & -9 & -8 & -14 & -11 & -12 & -10 \\
\hline & NLC & 0 & -2 & -3 & -4 & -3 & -1 & -2 & -3 & -3 \\
\hline & RLP & 7 & 9 & 8 & 5 & 5 & 13 & 9 & 9 & 8 \\
\hline \multirow[t]{3}{*}{ Xinjiang } & RULC & -6 & -13 & -9 & -8 & -7 & -16 & -14 & -11 & -11 \\
\hline & NLC & 2 & 0 & 3 & 4 & 6 & -2 & 2 & 3 & 1 \\
\hline & RLP & 8 & 12 & 12 & 12 & 13 & 14 & 16 & 13 & 12 \\
\hline
\end{tabular}

Notes: The bold values represent province's advantage $($ dulc $<0$, dnlc $<0$ or dlp $>0)$

Table 5 Decomposition of relative unit labour costs, 1995-2009 (Values have been timed 100)

\begin{tabular}{|c|c|c|c|c|c|c|c|c|c|c|}
\hline Province & $95-09$ & AtoB & $\mathrm{D}$ & $\mathrm{F}$ & G & I & $\mathbf{J}$ & $\mathrm{K}$ & M & $\mathrm{N}$ \\
\hline \multirow[t]{3}{*}{ Beijing } & RULC & 7 & 5 & 5 & 1 & 4 & -1 & 3 & 1 & 4 \\
\hline & NLC & 4 & 2 & 5 & -3 & -3 & -1 & 2 & 3 & 3 \\
\hline & RLP & -3 & -4 & -1 & -4 & -7 & 0 & -1 & 2 & -2 \\
\hline \multirow[t]{3}{*}{ Tianjin } & RULC & 6 & 5 & 6 & 0 & 6 & 4 & 5 & 0 & 0 \\
\hline & NLC & 6 & 3 & 7 & 4 & 4 & 3 & 5 & 5 & 5 \\
\hline & RLP & 0 & -2 & 1 & 4 & -1 & -1 & 0 & 5 & 4 \\
\hline \multirow[t]{3}{*}{ Hebei } & RULC & -1 & 0 & 2 & 2 & -2 & 4 & 0 & -2 & -3 \\
\hline & NLC & -1 & 1 & 2 & -2 & -1 & 0 & 0 & -2 & -2 \\
\hline & RLP & 0 & 0 & 0 & -4 & 2 & -4 & 0 & 0 & 1 \\
\hline \multirow[t]{3}{*}{ Shanxi } & RULC & -1 & 1 & 1 & -1 & 0 & 1 & 1 & -2 & -3 \\
\hline & NLC & 0 & 2 & 2 & -1 & 0 & 0 & 2 & 1 & 1 \\
\hline & RLP & 0 & 1 & 2 & 0 & 0 & -1 & 1 & 2 & 4 \\
\hline Inner Mongolia & RULC & 5 & 4 & 9 & -1 & 2 & 4 & 2 & 1 & 0 \\
\hline
\end{tabular}




\begin{tabular}{|c|c|c|c|c|c|c|c|c|c|c|}
\hline & NLC & 2 & 7 & 8 & 8 & 5 & 5 & 5 & 5 & 5 \\
\hline & RLP & -3 & 3 & 0 & 10 & 3 & 1 & 3 & 4 & 5 \\
\hline \multirow[t]{3}{*}{ Liaoning } & RULC & 1 & 2 & 2 & 2 & 2 & 2 & 2 & 2 & 3 \\
\hline & NLC & -1 & 4 & 6 & 5 & 2 & 1 & 4 & 1 & 1 \\
\hline & RLP & -2 & 1 & 4 & 3 & 0 & -1 & 2 & -1 & -2 \\
\hline \multirow[t]{3}{*}{ Jilin } & RULC & 0 & 1 & 1 & -1 & 3 & 3 & 3 & 1 & 1 \\
\hline & NLC & -4 & 4 & 5 & 5 & 1 & 1 & 2 & 1 & 1 \\
\hline & RLP & -4 & 3 & 4 & 6 & -2 & -3 & -1 & 0 & -1 \\
\hline \multirow[t]{3}{*}{ Heilongjiang } & RULC & 0 & 2 & 1 & 0 & 0 & 5 & 2 & -1 & 2 \\
\hline & NLC & -3 & 1 & 1 & 1 & 0 & -1 & -1 & 0 & 0 \\
\hline & RLP & -2 & -1 & 0 & 0 & 0 & -5 & -3 & 0 & -2 \\
\hline \multirow[t]{3}{*}{ shanghai } & RULC & 3 & 6 & 5 & 2 & 8 & 2 & 6 & 4 & 4 \\
\hline & NLC & 11 & 2 & 5 & 2 & 0 & -4 & 4 & 5 & 3 \\
\hline & RLP & 8 & -4 & 0 & 0 & -8 & -6 & -2 & 1 & -1 \\
\hline \multirow[t]{3}{*}{ Jiangsu } & RULC & 2 & 3 & 2 & 2 & 4 & 2 & 4 & 3 & 3 \\
\hline & NLC & 2 & 0 & 2 & 2 & 2 & 0 & 3 & 2 & 1 \\
\hline & RLP & 0 & -3 & 0 & 1 & -2 & -3 & -1 & -1 & -2 \\
\hline \multirow[t]{3}{*}{ Zhejiang } & RULC & 3 & 3 & 3 & 5 & 6 & -4 & 2 & 1 & 2 \\
\hline & NLC & 7 & -5 & -6 & -1 & 0 & -2 & -1 & -1 & -2 \\
\hline & RLP & 4 & -7 & -9 & -5 & -6 & 2 & -3 & -2 & -4 \\
\hline \multirow[t]{3}{*}{ Anhui } & RULC & 0 & 3 & -1 & 0 & 1 & 2 & 0 & -3 & -5 \\
\hline & NLC & -1 & 2 & 0 & 0 & 1 & -1 & 0 & -2 & -1 \\
\hline & RLP & -1 & -1 & 1 & -1 & 0 & -3 & 0 & 1 & 4 \\
\hline \multirow[t]{3}{*}{ Fujian } & RULC & 1 & 2 & 4 & 1 & 4 & 0 & 3 & 3 & 2 \\
\hline & NLC & -1 & -9 & -3 & -2 & -2 & -2 & -3 & -1 & -1 \\
\hline & RLP & -2 & -11 & -7 & -4 & -6 & -2 & -6 & -4 & -4 \\
\hline \multirow[t]{3}{*}{ Jiangxi } & RULC & 0 & 1 & 2 & -3 & 0 & 5 & 2 & 3 & 2 \\
\hline & NLC & 1 & 2 & -2 & 2 & -1 & 0 & -2 & -1 & -1 \\
\hline & RLP & 1 & 1 & -3 & 5 & -1 & -5 & -4 & -4 & -3 \\
\hline \multirow[t]{3}{*}{ Shandong } & RULC & 2 & 3 & 4 & 2 & 4 & 6 & 4 & 2 & 1 \\
\hline & NLC & 4 & -1 & -4 & 1 & 2 & 2 & 2 & 1 & 2 \\
\hline & RLP & 2 & -4 & -8 & -1 & -2 & -4 & -3 & 0 & 0 \\
\hline \multirow[t]{3}{*}{ Henan } & RULC & -1 & 0 & 1 & -1 & 1 & 2 & 3 & 1 & 2 \\
\hline & NLC & -3 & 0 & -3 & -4 & -2 & $\mathbf{0}$ & -2 & -3 & -2 \\
\hline & RLP & -2 & 0 & -3 & -2 & -2 & -2 & -5 & -4 & -4 \\
\hline \multirow[t]{3}{*}{ Hubei } & RULC & -1 & 2 & 0 & 2 & 1 & 1 & 1 & -1 & 1 \\
\hline & NLC & 0 & 1 & -1 & 1 & 0 & 1 & 0 & 0 & 0 \\
\hline & RLP & 1 & -1 & -1 & -2 & -1 & 0 & -2 & 1 & -1 \\
\hline \multirow[t]{3}{*}{ Hunan } & RULC & -2 & 0 & 0 & -1 & 0 & 0 & 0 & -3 & -4 \\
\hline & NLC & 6 & 0 & -6 & 1 & -1 & -2 & -3 & -2 & -3 \\
\hline & RLP & 7 & 0 & -6 & 3 & -1 & -1 & -2 & 0 & 2 \\
\hline \multirow[t]{2}{*}{ Guangdong* } & RULC & 2 & 2 & 10 & -2 & 4 & -1 & 3 & 6 & 4 \\
\hline & NLC & 3 & -4 & 2 & 0 & -1 & 1 & -2 & 0 & -1 \\
\hline
\end{tabular}




\begin{tabular}{|c|c|c|c|c|c|c|c|c|c|c|}
\hline & RLP & 1 & -7 & -8 & 2 & -4 & 1 & -5 & -6 & -5 \\
\hline \multirow[t]{3}{*}{ Guangxi } & RULC & -3 & -1 & -2 & 0 & -1 & -4 & -1 & -1 & -2 \\
\hline & NLC & -4 & -4 & -4 & -6 & -5 & -3 & -5 & -4 & -5 \\
\hline & RLP & -2 & -3 & -3 & -5 & -3 & 1 & -4 & -3 & -4 \\
\hline \multirow[t]{3}{*}{ Sichuan* } & RULC & -1 & 2 & 4 & 0 & -1 & 0 & 1 & 0 & 1 \\
\hline & NLC & -2 & 0 & -4 & 1 & 0 & -1 & -2 & -1 & -1 \\
\hline & RLP & -1 & -2 & -8 & 0 & 1 & -1 & -3 & -1 & -1 \\
\hline \multirow[t]{3}{*}{ Guizhou } & RULC & 0 & 0 & -2 & -1 & -8 & -2 & -2 & -7 & -9 \\
\hline & NLC & 0 & -1 & -3 & -5 & -1 & -1 & -5 & -2 & -1 \\
\hline & RLP & 1 & -1 & -1 & -4 & 8 & 2 & -2 & 5 & 8 \\
\hline \multirow[t]{3}{*}{ Yunnan } & RULC & -1 & 2 & -2 & 1 & 4 & 0 & 3 & 5 & 1 \\
\hline & NLC & -2 & -1 & -1 & -2 & -1 & -1 & -2 & -1 & -2 \\
\hline & RLP & -1 & -3 & 1 & -3 & -4 & 0 & -5 & -6 & -2 \\
\hline \multirow[t]{3}{*}{ Shaanxi } & RULC & 1 & 0 & 0 & -4 & 1 & 2 & 3 & 0 & 0 \\
\hline & NLC & -2 & 2 & 3 & -2 & -1 & 1 & -2 & 1 & 1 \\
\hline & RLP & -2 & 2 & 3 & 2 & -2 & -1 & -5 & 0 & 1 \\
\hline \multirow[t]{3}{*}{ Gansu } & RULC & -2 & 2 & -2 & 4 & -1 & 5 & 3 & -2 & -2 \\
\hline & NLC & -2 & 2 & 1 & 0 & 0 & 1 & 0 & -1 & 1 \\
\hline & RLP & 0 & -1 & 3 & -4 & 1 & -5 & -2 & 1 & 3 \\
\hline \multirow[t]{3}{*}{ Qinghai } & RULC & -1 & 0 & 2 & 1 & 0 & 3 & 3 & 2 & 1 \\
\hline & NLC & -1 & 4 & 5 & 0 & -1 & 2 & -4 & 0 & -1 \\
\hline & RLP & 0 & 4 & 4 & -1 & -1 & -1 & -7 & -2 & -1 \\
\hline \multirow[t]{3}{*}{ Ningxia } & RULC & 1 & 1 & -1 & 1 & -5 & 1 & -1 & -5 & -6 \\
\hline & NLC & 1 & 2 & 0 & 1 & 1 & 2 & 1 & 2 & 1 \\
\hline & RLP & -1 & 1 & 1 & 0 & 6 & 0 & 2 & 7 & 7 \\
\hline \multirow[t]{3}{*}{ Xinjiang } & RULC & -1 & -3 & 1 & 2 & 1 & 0 & 2 & -1 & -2 \\
\hline & NLC & -2 & 1 & 0 & -2 & -1 & -1 & -3 & -2 & -3 \\
\hline & RLP & -1 & 4 & -1 & -4 & -3 & -1 & -5 & -1 & -1 \\
\hline
\end{tabular}

Notes: The bold values represent province's advantage (dulc $<0$, dnlc $<0$ or dlp $>0$ )

Table 6 Annual growth rates of coefficients of variation

\begin{tabular}{|c|c|c|c|c|c|c|c|c|c|}
\hline & AtoB & $\mathrm{D}$ & $\mathrm{F}$ & $\mathrm{G}$ & $\mathrm{I}$ & $\mathrm{J}$ & $\mathrm{K}$ & $\mathrm{M}$ & $\mathrm{N}$ \\
\hline & \multicolumn{10}{|c|}{ Relative unit labour costs } \\
\hline $1978-1995$ & -0.02 & -0.01 & -0.05 & -0.04 & -0.03 & -0.01 & -0.03 & -0.06 & -0.03 \\
\hline $1995-2009$ & 0.07 & 0.01 & 0.09 & 0.00 & 0.01 & -0.03 & 0.02 & 0.11 & 0.07 \\
\hline & \multicolumn{10}{|c|}{ Relative labour productivity } \\
\hline $1978-1995$ & -0.01 & -0.01 & 0.00 & 0.01 & 0.01 & 0.00 & -0.01 & -0.03 & -0.06 \\
\hline $1995-2009$ & 0.01 & -0.03 & 0.00 & -0.01 & -0.02 & -0.01 & -0.01 & 0.04 & 0.01 \\
\hline & \multicolumn{10}{|c|}{ Relative nominal labour costs } \\
\hline $1978-1995$ & -0.01 & 0.01 & -0.02 & 0.01 & 0.02 & 0.02 & -0.04 & -0.04 & -0.07 \\
\hline $1995-2009$ & 0.02 & -0.02 & 0.02 & 0.01 & 0.00 & -0.01 & 0.02 & 0.05 & 0.03 \\
\hline
\end{tabular}




\section{Figure 1 Coefficients of variations of RULC}

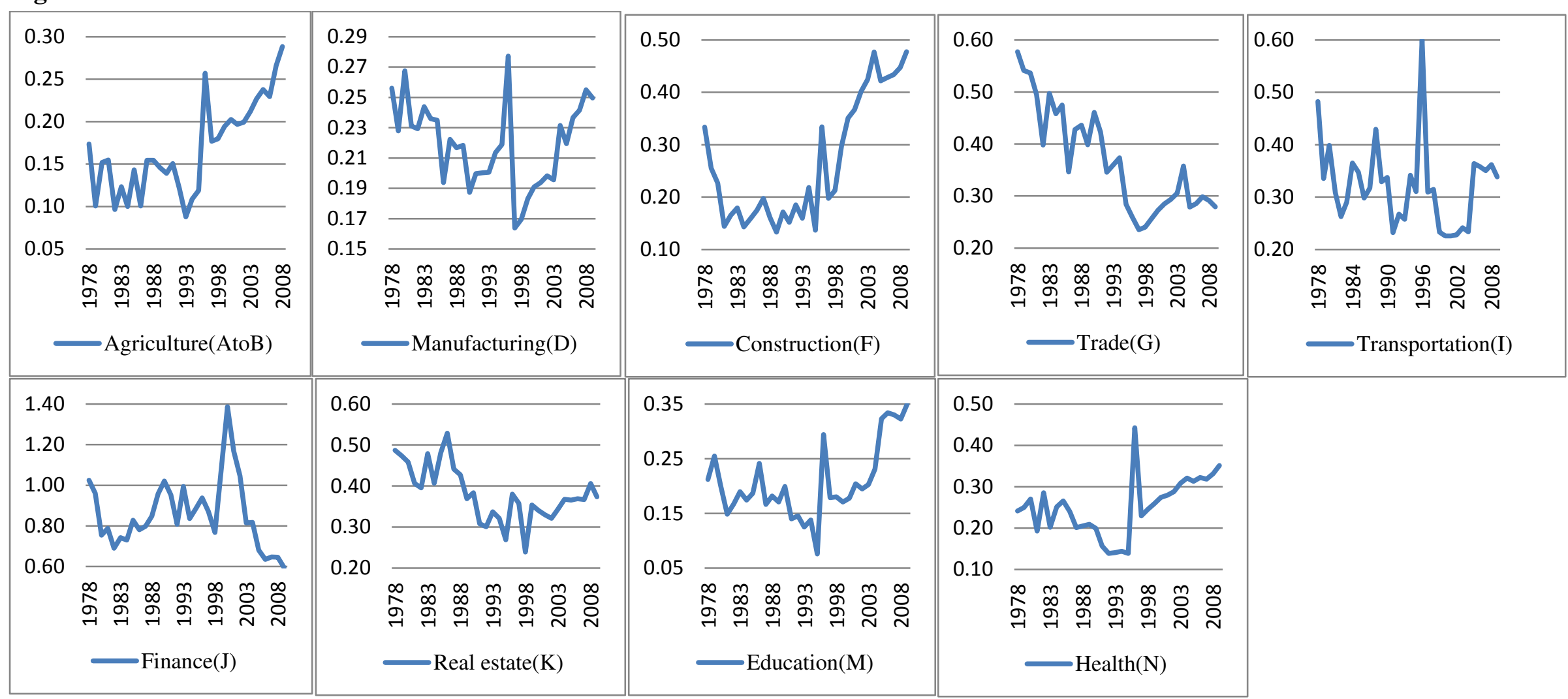

